\title{
First Premolar Morphometry: A Study in 54 Cases
}

\author{
Morfometría de Primeros Premolares: un Estudio de 54 Casos
}

"Ramón Fuentes F.; "Eduardo Borie E.; **Luis Bustos M. \& *David Tomas M.

\begin{abstract}
FUENTES, F. R.; BORIE, E. E.; BUSTOS, M. L. \& TOMAS, M. D. First premolar morphometry: A study in 54 cases. Int. J. Morphol., 29(1):234-239, 2011.

SUMMARY: First lower premolars are the teeth with greater variations following third molars. Fifty four first premolars extracted by orthodontic indication from patients in Temuco, Chile, were studied and classified by age, sex and maxillar and mandible location. The following parameters were measured: vestibular-palatine diameter (VP), mesiodistal (MD) diameter, coronary height (C-O), root length and total length. The data were statistically analyzed and tabulated. The results exhibited that first upper premolars showed higher values in the VP diameter and root length compared with the lower, noting significant differences. Further, male sex showed higher values on most measures compared with females, except in root length. Finally a difference in root length was observed between first upper and lower premolars.
\end{abstract}

KEY WORDS: Premolars; Odontometry; Anthropology; Dentistry.

\section{INTRODUCTION}

Morphometry has always been one of the most common approaches to physical anthropology, providing greater information in as far as anatomy, relations, pathologies and developmental issues (Mantini \& Ripani, 2009; Gomez-Robles et al., 2007), state that teeth are the source or valuable and reliable information for anthropological research. Furthermore, and as complement to dental anthropology, odontometry is used which refers to the use of information corresponding to dental dimensions in evolutionary and comparative studies to establish the relation between hominid species that have disappeared and modern human beings (Rodríguez, 2004). The above should not be confused with odontoscopy or dental morphology which objective mainly is to observe, register, analyze and understand the behavior of crown and root morphology in human teeth (Girón et al., 2009).

Girón et al. (2009) assure that teeth morphology is conformed by a series of characteristics that have been called crown and root dental morphological traits that constitute in enamel phenotype forms expressed and regulated by the genome of an individual and that of a population during odontogenesis. Despite the above, there are few specific morphological studies of premolars; however the relevance that descriptive knowledge of these teeth has, is reflected in the information presented by Martinón-Torres et al. (2006) who underscore that inferior premolars allow the taxonomy classification of hominids, a fundamental aspect of human evolution. The first premolars are esthetically visible teeth wherein their rehabilitation plays a crucial role, as these teeth sustain fractures more frequently (Nothdurft et al., 2008).

Anatomy of the first premolars is of great clinical relevance in the oral rehabilitation areas in view of direct crown esthetics as well as leverage force exerted on the roots during mastication, where the root-crown relation is relevant. Additionally, Swart \& van Niekerk (2008) mention that the most acceptable treatment option is an implant to replace a premolar when it cannot be completely restored; however, in order to locate the implant it is necessary to understand the radicular and coronal anatomy of premolars for their subsequent rehabilitation.

Therefore, with respect to anatomical characteristics of premolars, literature describes a pentagonal form for the

\footnotetext{
* Departamento de Odontología Integral, Universidad de La Frontera, Temuco, Chile

** Centro de Excelencia CIGES, Universidad de La Frontera, Temuco, Chile.
} 
first upper premolars where the vestibule palatine diameter predominates over the mesiodistal diameter (Figún \& Garino, 2002), presenting an average total length of 22.5 mm (Ash \& Nelson, 2006; Sicher \& Dubrul, 1991), a crown length that varies in range from $8 \mathrm{~mm}$ to $8.7 \mathrm{~mm}$ (Figún \& Garino; Sicher \& Dubrul; Velayos \& Santana, 2001; Ash \& Nelson; Esponda Vila, 2009) and a root length of approximately $14 \mathrm{~mm}$ (Esponda Vila; Ash \& Nelson). Furthermore, these present a mesiodistal diameter of $7 \mathrm{~mm}$, and vestibule palatine of $9 \mathrm{~mm}$ (Ash \& Nelson; Sicher \& Dubrul; Figún \& Garino). In a study carried out in first maxillary premolars in Jordan it was observed that $63.2 \%$ had two roots, $30.8 \%$ only one root and $5.2 \%$ had bifid roots (Awawdeh et al., 2008).

It is worthwhile noting that the first lower premolars generally present an ovoid occlusal outline (Figún \& Garino), observing a total average length of $21 \mathrm{~mm}$ (Velayos Santana; Esponda Vila), with crown length of $7.8 \mathrm{~mm}$ (Figún \& Garino), and a root length of $14 \mathrm{~mm}$ (Nelson; Figún \& Garino; Sicher \& Dubrul). However, mandibular premolars have gained a reputation for having an aberrant anatomy (Nallapati, 2005; Sachdeva et al., 2008). In a study carried out with first mandibular premolars in Iran a prevalence of $88.47 \%$ with single root was observed (Khedmat et al., 2010).

Considering that no literature was found of Chilean studies, the present study was realized to describe the morphometric characteristics in a group of 54 premolars.

\section{MATERIAL AND METHOD}

Fifty four (54) first premolars were studied, extracted by orthodontic indication at the Clínica Odontologica Docente Asistencial (CODA) of the Universidad de La Frontera, Temuco. They were classified by age, sex and location in the maxila and mandible (Fig.1). For the sample, all first premolars that did not present completely formed roots with apical closure, or crowns with loss of integrity were discarded. The following parameters were measured with a Bull Tools 0-150 mm digital caliper:

- Total length, from the cusp vertex to root apex.

- Cervical height diameter or cervical occlusal distance (C-O), from the cusp vertex most prominent to the central area of the cementum enamel junction (Figs. 2 and 3).

- Root length from central cementum enamel junction to root apex (Figs. 2 and 3).

- Vestibular palatine diameter (V-P), the greater length in that direction (Fig. 2).

- Mesiodistal diameter (M-D), the greater coronary length in that direction.

The number of roots was quantified, identifying the premolars that presented anomalies in their form.

The information was tabulated in Microsoft Excel, statistical analysis was realized by STATA software version 9.0 working with significance value set at $5 \%$.
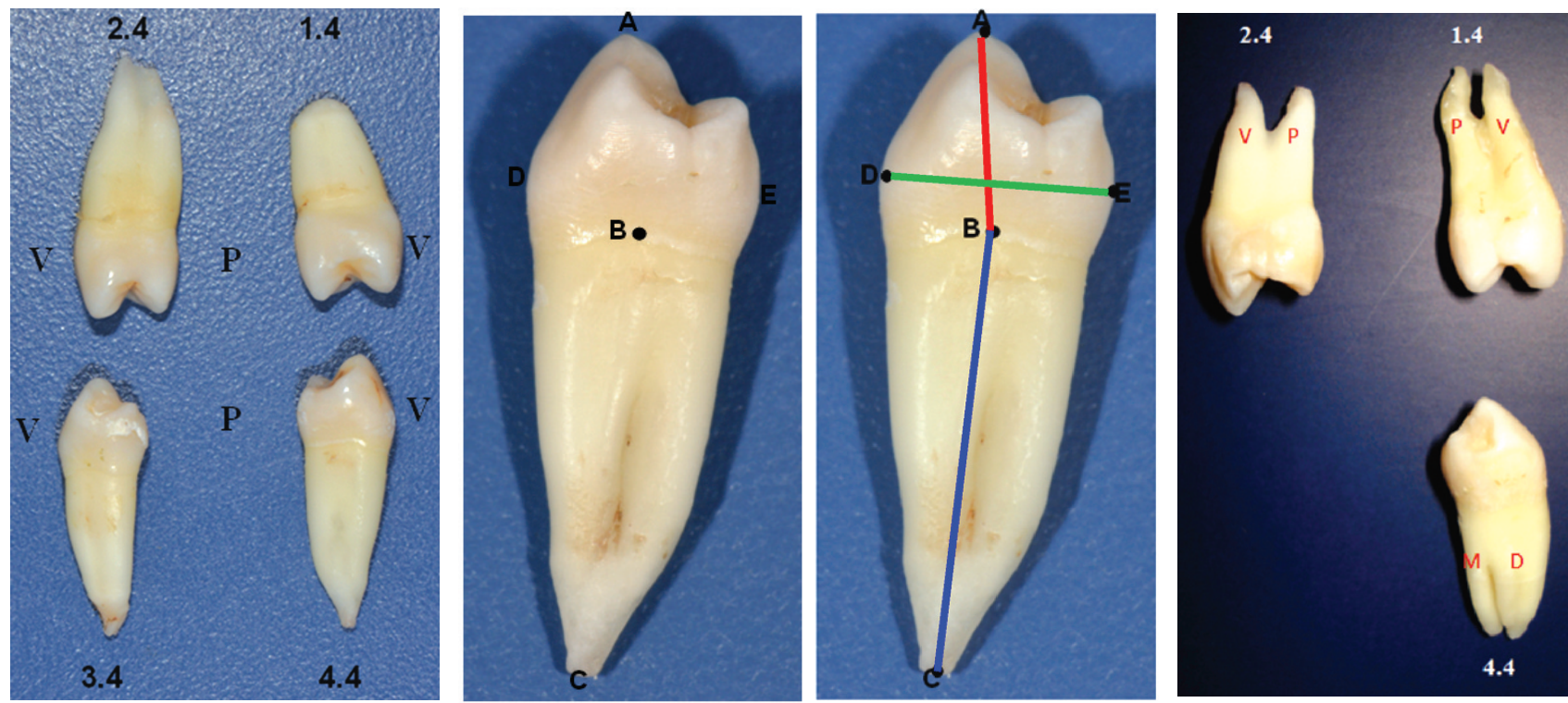

Fig. 1. First premolars according to location in the maxilla. V: vestibular surface; P: palatine surface.

Fig. 2. Reference points to carry out measures. A: Highest point in the most prominent cuspid. B: middle cement-enamel junction. C: Furthest apical point; D: Most prominent vestibular point; E: Most prominent lingual point.

Fig. 3. Outline of the different measures. Red: Cervical-occlusal height (points of union A-B); Blue: Root length (points of union B-C); Green: Vestibular-palatine diameter (points of union D-E).

Fig. 4. First birradicular premolars according to location in the maxillary molars. V: Vestibular root; P:Palatine root; M: Mesial root; D: Distal root. 


\section{RESULTS}

Of the 54 first premolars studied 63\% corresponded to teeth extracted from women $(n=34)$ and $37 \%$ men $(n=20)$, with a median age of patients of 19.1 years (15-60 years). Of the total of first premolars analyzed $14(26 \%)$ were first upper right premolars, 17 upper left (31.5\%), 11 lower left (20.4\%) and 12 lower right (22.1\%). The results are as follows in Tables I, II and III.

In as far as V-P distance of the different teeth studied a value of $p=0$, was observed, indicating that at least an average of the vestibular palatine diameter in the various teeth is different, noting significant differences in the averages of maxillary teeth with mandible teeth, with a greater V-P diameter in the maxillary teeth. Statistically significant results were not observed for averages of the M$\mathrm{D}$ distance or averages for $\mathrm{C}-\mathrm{O}$ distance.

For root length the results indicate that there are significant statistical differences $(p=0.0280)$, with greater length averages in the first lower premolars.

In reference to the M-D distance according to sex, statistically significant results were observed $(p=0.0041)$, with a greater average of the mesiodistal distance for men. Furthermore, for the $\mathrm{C}-\mathrm{O}$ distance significant figures were observed $(p=0.0094)$, with a greater average found in men over women. However, no significant differences were observed between men and women for the V-P distance averages, root length and total length.

In Table III a clear tendency toward men can be observed with greater values in the V-P, M-D and C-O diameter measures can be observed; nevertheless for root length it was observed that in woman greater figures were obtained. Greater figures in root length were observed in the lower premolars. Also, for V-P diameter significant differences were observed only for teeth 3 and 4 , with a greater median for males above females. In M-D distance, significant differences were only observed for teeth 2 and 4 with a greater median observed for men. Additionally for the $\mathrm{C}-\mathrm{O}$ distance statistically significant results were observed for teeth 4.4 , noting a greater median in men. In root length of the different teeth according to location no significant results were observed between men and women.

It is worthwhile mentioning that for upper premolars predominant occlusal form was quadrangular with vestibular palatine diameter predominating above the mesiodistal; in the inferior premolars the pentagonal occlusal form prevailed.

It should be noted that of the first 54 premolars analyzed, eight had two roots, of these four were 1.4 pieces, three were 2.4, and one was 4.4 (Fig. 4).

Table I. Relation of clinical measures according to the number of teeth. ANOVA.

\begin{tabular}{|c|c|c|c|c|c|c|c|c|c|}
\hline \multirow{2}{*}{$\begin{array}{l}\text { Measures } \\
(\mathrm{mm})\end{array}$} & \multicolumn{2}{|c|}{ P $1.4(\mathrm{n}=14)$} & \multicolumn{2}{|c|}{ P $2.4(\mathrm{n}=17)$} & \multicolumn{2}{|c|}{ P $3.4(n=11)$} & \multicolumn{2}{|c|}{ P $4.4(n=12)$} & \multirow[t]{2}{*}{$\mathrm{P}$} \\
\hline & $\mathrm{X}$ & S.D. & $\mathrm{X}$ & S.D. & $\mathrm{X}$ & S.D. & $\mathrm{X}$ & S.D. & \\
\hline DistanceV-P & 9.75 & $0 . .45$ & 9.80 & 0.44 & 7.99 & 0.58 & 7.99 & 0.51 & $0.0000^{*}$ \\
\hline Distance M-D & 7.39 & 0.48 & 7.16 & 0.42 & 7.45 & 0.44 & 7.49 & 0.30 & 0.1468 \\
\hline Distance C-O & 8.96 & 0.73 & 8.62 & 0.59 & 8.71 & 0.94 & 8.95 & 0.59 & 0.4930 \\
\hline Root length & 12.80 & 1.79 & 12.96 & 2.15 & 14.46 & 1.07 & 14.34 & 1.49 & $0.0280 *$ \\
\hline Total length & 21.76 & 1.12 & 21.58 & 1.24 & 23.17 & 0.94 & 23.29 & 0.98 & 0.3570 \\
\hline
\end{tabular}

Table II. Relation for clinical measures according to gender. ANOVA.

\begin{tabular}{lccccccc}
\multicolumn{1}{c}{\begin{tabular}{c} 
Measures \\
\multicolumn{1}{c}{$(\mathrm{mm})$}
\end{tabular}} & $\mathrm{n}$ & $\mathrm{X}$ & S.D. & \multicolumn{1}{c}{$\mathrm{n}$} & $\mathrm{X}$ & S.D. & $\mathrm{p}$ \\
Distance V-P & 34 & 8.88 & 0.97 & 20 & 9.23 & 1.06 & 0.2252 \\
Distance M-D & 34 & 7.22 & 0.42 & 20 & 7.57 & 0.37 & $0.0041^{*}$ \\
Distance C-O & 34 & 8.61 & 0.63 & 20 & 9.12 & 0.66 & $0.0094^{*}$ \\
Root length & 34 & 13.65 & 1.83 & 20 & 13.34 & 1.93 & 0.5671 \\
Total length & 34 & 22.26 & 0.97 & 20 & 22.46 & 1.02 & 0.3256
\end{tabular}


FUENTES, F. R.; BORIE, E. E.; BUSTOS, M. L. \& TOMAS, M. D. First premolar morphometry: A study in 54 cases. Int. J. Morphol., 29(1):234-239, 2011.

Table III. Relation between gender according to tooth clinical measurements. ANOVA.

\begin{tabular}{|c|c|c|c|c|c|c|c|c|c|}
\hline$(\mathrm{mm})$ & 1.4 & 2.4 & 3.4 & 4.4 & $(\mathrm{~mm})$ & 1.4 & 2.4 & 3.4 & 4.4 \\
\hline $\begin{array}{l}\text { Dimeter V-P } \\
\text { Women }\end{array}$ & & & & & $\begin{array}{l}\text { Diameter M-D } \\
\text { Women }\end{array}$ & & & & \\
\hline $\mathrm{X}$ & 9.58 & 9.67 & 7.69 & 7.95 & $\mathrm{X}$ & 7.33 & 7.00 & 7.26 & 7.42 \\
\hline S.D. & 0.46 & 0.37 & 0.28 & 0.34 & S.D. & 0.53 & 0.36 & 0.33 & 0.29 \\
\hline P50 & 9.7 & 9.67 & 7.73 & 8 & P50 & 7.33 & 7 & 7.45 & 7.52 \\
\hline Men & & & & & Men & & & & \\
\hline X & 10.07 & 10.03 & 8.52 & 8.02 & X & 7.50 & 7.46 & 7.79 & 7.58 \\
\hline S.D. & 0.25 & 0.51 & 0.60 & 0.74 & S.D. & 0.42 & 0.36 & 0.44 & 0.32 \\
\hline P50 & 9.97 & 9.84 & 8.37 & 8.19 & P50 & 7.3 & 7.49 & 7.82 & 7.59 \\
\hline $\mathrm{P}$ & 0.053 & 0.227 & $0.014^{*}$ & 0.569 & $\mathrm{P}$ & 0.548 & $0.018^{*}$ & 0.058 & 0.684 \\
\hline Distance $\mathrm{C}-\mathrm{O}$ & & & & & Root length & & & & \\
\hline Women & & & & & Women & & & & \\
\hline $\mathrm{X}$ & 8.72 & 8.60 & 8.43 & 8.67 & X & 13.11 & 13.36 & 14.07 & 14.37 \\
\hline S.D. & 0.80 & 0.62 & 0.65 & 0.44 & S.D. & 2.09 & 2.19 & 1.07 & 1.39 \\
\hline P50 & 8.90 & 8.50 & 8.28 & 8.56 & P50 & 12.94 & 12.96 & 14.01 & 13.73 \\
\hline Men & & & & & Men & & & & \\
\hline $\mathrm{X}$ & 9.39 & 8.66 & 9.20 & 9.35 & $\mathrm{X}$ & 12.26 & 12.25 & 15.15 & 14.29 \\
\hline S.D. & 0.32 & 0.58 & 1.26 & 0.58 & S.D. & 1.05 & 2.07 & 0.74 & 1.79 \\
\hline P50 & 9.54 & 8.64 & 9.70 & 9.44 & P50 & 12.23 & 11.83 & 15.43 & 14.25 \\
\hline $\mathrm{P}$ & 0.053 & 0.847 & 0.344 & $0.042 *$ & $\mathrm{P}$ & 0.463 & 0.314 & 0.130 & 0.935 \\
\hline
\end{tabular}

\section{DISCUSSION}

According to previously presented results it is possible to interpret the following:

First upper premolars (1.4-2.4)

Total length: Length noted in the first upper premolars was 21.76 and $21.58 \mathrm{~mm}$ for 1.4 and 2.4 pieces respectively. These values are similar to those of $21.6 \mathrm{~mm}$ reported by Sandhya et al. (2010). However, these values are greater than those presented by Esponda Vila and Velayos Santana $(20 \mathrm{~mm})$ but less than those noted by Sicher \& Dubrul and Ash \& Nelson (22.5 mm).

Crown length: Crown length (C-O distance) was 8.96 $\mathrm{mm}$ and $8.62 \mathrm{~mm}$ for teeth 1.4 and 2.4 respectively. These figures are close to the $8.5 \mathrm{~mm}$ and $8.7 \mathrm{~mm}$ reported by Ash $\&$ Nelson and Sicher and Dubrul, respectively, although greater to the $8 \mathrm{~mm}$ commented by Figún \& Garino and Velayos Santana.

Root length: Values of $12.8 \mathrm{~mm}$ were observed for teeth 1.4 and 12.96 for teeth 2.4 , which are similar to the 13 mm reported by Figún \& Garino, but less than the $14 \mathrm{~mm}$ reported by Ash \& Nelson and Sicher \& Dubrul.

Vestibular-palatine diameter: Authors as Esponda Vila, Ash \& Nelson, Sicher \& Dubrul and Figún \& Garino reported values less $(9 \mathrm{~mm})$ in comparisson with the 9.75 and $9.8 \mathrm{~mm}$ found in this study.

Mesiodistal diameter: Values found were $7.39 \mathrm{~mm}$ for teeth 1.4 and 7.16 for teeth 2.4 , with results similar to those reported by Esponda Vila $(7.2 \mathrm{~mm})$ and Sicher \& Dubrul (7 mm).

It is important to note that statements made by Figún \& Garino who note that first upper premolars have pentagonal crown form, are not met, since clear predomination of rectangular form was observed in $77.4 \%$ of these. However, it does concur that, in these, vestibular-palatine diameter is predominant over the mesiodistal diameter.

In reference to the amount of roots in first upper premolars it was observed that, in $22.5 \%$ of these two roots were presented, cipher less than the $63.2 \%$ reported in Jordan by Awawdeh et al.

First lower premolars (3.4-4.4)

Total length: The length found was of $23.17 \mathrm{~mm}$ and 23.29 $\mathrm{mm}$ for teeth 3.4 and 4.4 , respectively. These values do not concur and are greater to values proposed by Velayos Santana $(21.3 \mathrm{~mm})$, Esponda Vila $(21 \mathrm{~mm})$ and Ash \& Nelson $(22.5 \mathrm{~mm})$. 
Crown length: The crown length (C-O distance) for the lower was $8.71 \mathrm{~mm}$ for teeth 3.4 and $8.95 \mathrm{~mm}$ for 4.4 , close to the $8.5 \mathrm{~mm}$ reported by Ash \& Nelson; however, much greater to the $7.8 \mathrm{~mm}$ mentioned by Figun \& Garino and Esponda Vila. Further, Sicher \& Dubrul found lengths greater than $9.2 \mathrm{~mm}$.

Root length: Root length of $14.46 \mathrm{~mm}$ and $14.34 \mathrm{~mm}$ was observed for teeth 3.4 and 4.4, respectively. These results are very close to the $14 \mathrm{~mm}$ reported by Ash \& Nelson and Esponda Vila and to the $14.6 \mathrm{~mm}$ reported by Figún \& Garino.

Vestibular palatine distance: Value found was $7.99 \mathrm{~mm}$ for lower premolars; however values of $7.5 \mathrm{~mm}$ are mentioned in the literature (Figun \& Garino; Velayos \& Santana; Sicher \& Dubrul).

Mesiodistal distance: The average distance found was 7.45 $\mathrm{mm}$ for teeth 3.4 and 7.49 for 4.4. The above was slightly greater to the $7 \mathrm{~mm}$ reported by Ash \& Nelson and Sicher \& Dubrul.

It is worthwhile noting that the first lower premolars generally present an ovoidal occlusal form (Figún \& Garino); however, at that time a predominance of pentagonal occlusal form of $69.5 \%$ was observed, which could be due to teeth having greater variations following third molars (Sachdeva et al.; Fuentes et al., 2009). Further, it was observed that the first lower premolars presented greater root length than upper premolars. Which does not concur with Ash \& Nelson, since the authors point out that both lengths are equal. In reference to the number of roots of first lower premolars, $4.35 \%$ were found with two roots, cipher less than the $11.53 \%$ mentioned by Khedmat $e t$ al. Another important aspect observed was the root-crown relation which resulted more successfully for lower premolars than for upper premolars; situation of great relevance for the preparation of fixed prostheses of these teeth.
In general it is important to underscore observations between clinical measures and number of pieces (Table I), where vestibular palatine diameter and root length showed significant differences between first lower premolars and upper premolars, with higher values of the V-P distance in the latter.

In reference to the clinical measures comparison of the first premolars according to sex (Table II), a tendency toward higher values was found in males over females, noting significant differences in the mesiodistal as well as cervicalocclusal diameter.

In conclusion in clinical measures between sex and dental pieces (Table III) greater values can be observed in V$\mathrm{P}, \mathrm{M}-\mathrm{D}$ and $\mathrm{C}-\mathrm{O}$ diameter measures for males. In females however, the greatest results were observed in root length, with greater lengths in the first lower premolars. It should be noted also that important differences were in the vestibular palatine diameter of teeth 3.4 , in the mesiodistal diameter in teeth 2.4 and cervical-occlusal distance in pieces 4.4 , always obtaining values in the upper median in males than females, excepting root length.

A clear tendency toward greater values in males over females was observed, excepting in root length. Further, in the first upper premolars the vestibular palatine diameter predominated with rectangular form when compared with first lower premolars with a more quadrangular or pentagonal form. At the same time the root-crown relation was more favorable in lower premolars, and occlusal height and width was greater in males; both situations are of great important at the time of preparing fixed prosthesis in these dental pieces. Root length of lower premolars was greater than upper premolars in both sexes; $22.5 \%$ of first maxillary premolars were found to be double rooted while $4.35 \%$ of mandibular premolars were double rooted.

FUENTES, F. R.; BORIE, E. E.; BUSTOS, M. L. \& TOMAS, M. D. Morfometría de primeros premolares: Un estudio de 54 casos. Int. J. Morphol., 29(1):234-239, 2011.

RESUMEN: Los primeros premolares inferiores son las piezas dentarias con mayores variaciones después de los terceros molares. Se estudiaron 54 primeros premolares extraídos por ortodoncia de pacientes de la ciudad de Temuco, Chile, los cuales fueron clasificados por edad, género y ubicación en los maxilares y en la mandíbula. Se midieron los siguientes parámetros: diámetro vestíbulopalatino (V-P), mesio-distal (M-D), altura coronaria (C-O), longitud radicular y longitud total. Los datos fueron analizados estadísticamente y tabulados. Los resultados arrojaron que los primeros premolares superiores presentaron valores superiores en el diámetro V-P y la longitud radicular con respecto a los inferiores, observando diferencias estadísticamente significativas. Además, en los hombres se observaron valores superiores en la mayoría de las mediciones, a excepción de la longitud radicular. Finalmente, se observó una diferencia en la longitud radicular entre los primeros premolares maxilares y los mandibulares.

PALABRAS CLAVE: Premolares; Odontometría; Antropología; Odontología. 


\section{REFERENCES}

Ash, M. M. \& Nelson, S. J. Wheeler`s Anatomía, Fisiología y Oclusión Dental. $8^{\mathrm{a}}$ Ed. Barcelona, Elsevier, 2006. pp.285-92; 320-8.

Awawdeh, L.; Abdullah, H.; Al-Qudah, A. Root form and canal morphology of Jordanian maxillary first premolars. J. Endod., 34(8):956-61, 2008.

Esponda Vila, R. Anatomía Dental. $7^{\mathrm{a}}$ Ed. México Edit. Universidad Nacional Autónoma de México, 2009. pp.195-238.

Figún, M. E. \& Garino, R. R. Anatomía Odontológica Funcional y Aplicada. $2^{\text {a }}$ Ed. Buenos Aires, El Ateneo, 2002. pp. 234-40.

Fuentes, R.; Borie, E.; Bustos, L. \& Thomas, D. Morfometría de terceros molares: un estudio de 55 casos. Int. J. Morphol., 27(4):1285-9, 2009.

Girón, G.; Gómez, P.; Morales, L.; León, M.; Moreno, F. Rasgos morfológicos y métricos dentales coronales de premolares superiores e inferiores en escolares de tres instituciones educativas de Cali, Colombia. Int. J. Morphol., 27(3):913-25, 2009.

Gómez-Robles, A.; Martinón-Torres, M.; Bermúdez de Castro, J.M.; Margvelashvili, A.; Bastir, M.; Arsuaga, J.L.; Pérez-Pérez, A.; Estebaranz, F.; Martínez L.M. A geometric morphometric analysis of hominin upper first molar shape. J. Hum. Evol., 53(3):272-85, 2007.

Khedmat, S.; Assadian, H.; Saravani, A. A. Root canal morphology of the mandibular first premolars in an Iranian population using cross-sections and radiography. J. Endod., 36(2):214-7, 2010.

Mantini, S. \& Ripani, M. Modern morphometry: new perspectives in physical anthropology. N. Biotechnol., 25(5):325-30, 2009.

Martinón-Torres, M.; Bastir, M.; Bermúdez de Castro, J.M.; Gómez, A.; Sarmiento, S.; Muela, A.; Arsuaga, J. L. Hominin lower second premolar morphology: evolutionary inferences through geometric morphometric analysis. J. Hum. Evol., 50:523-33, 2006.

Nallapati, S. Three canal mandibular first and second premolars: a treatment approach. J. Endod., 31(6):4746, 2005.
Nothdurft, F. P.; Seidel, E.; Gebhart, F.; Naumann, M.; Motter, P. J. \& Pospiech, P. R. The fracture behavior of premolar teeth with class II cavities restored by both direct composite restorations and endodontic post systems. J. Dent., 36(6):444-9, 2008.

Rodríguez, C. La antropología dental y su importancia en el estudio de los grupos humanos prehispánicos. Rev. Antropol. Exp., 4:1-7, 2004

Sachdeva, G. S.; Ballal, S.; Gopikrishna, V. \& Kandaswamy, D. Endodontic Management of a Mandibular Second Premolar with Four Roots and Four Root Canals with the Aid of Spiral Computed Tomography: A Case Report. J. Endod., 34(1):104-7, 2008.

Sandhya, R.; Velmurugan, N.; Kandaswamy, D. Assessment of root canal morphology of mandibular first premolars in the Indian population using spiral computed tomography: An in vitro study. Indian J. Dent. Res., 21(2):169-73, 2010.

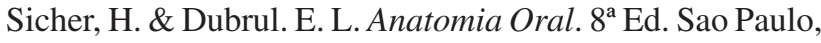
Artes Médicas, 1991. pp.157-62.

Swart, L. C. \& van Niekerk, D. J. Simplifying the implant treatment for an unrestorable premolar with a one-piece implant: A clinical report. J. Prosthet. Dent., 100(2):815, 2008 .

Velayos, J. L. \& Santana, H. Anatomía de la Cabeza. $3^{\mathrm{a}}$ Ed. Madrid, Medica Panamericana, 2001. pp.104-5.

Correspondence to:

Ramón Fuentes Fernández

Depto. Odontología Integral

Universidad de La Frontera

Manuel Montt 112

Temuco-CHILE

Email: rfuentes@ufro.cl

Received: 20-10-2010

Accepted: 20-11-2010 